ORIGINAL ARTICLE

\title{
"As vast as the world" - reflections on A Very Easy Death by Simone de Beauvoir
}

\section{F Brennan}

J Med Ethics; Medical Humanities 2004;30:85-90. doi: 10.1136/jmh.2004.000163

In 1964, Simone de Beauvoir, arguably one of the greatest writers of 20th century Europe, published an account of the final 6 weeks of her mother's life. It is a beautifully written, raw, honest, and powerful evocation of that period from the viewpoint of a relative. Its themes are universal-love, ambivalence in family ties, loss, and bereavement. Given that the events preceded the modern palliative care movement, reflections are made on differences in medical practice since the book's publication.

(n) 78 year old woman has two daughters. She has been widowed for 24 years. She begins to complain of anorexia and intermittent abdominal pain. The symptoms abate. One day she collapses at her home. Her left femur is fractured. She is admitted to hospital. The gastrointestinal symptoms return. After a series of investigations, she is discovered to have a sarcoma involving the small intestine. Soon after, she develops, in rapid succession, an acute bowel obstruction, ruptured viscus, and peritonitis. A laparotomy is performed, pus is drained, and the tumour resected. Complications ensue and she dies four weeks after the operation. At no stage is either her diagnosis or prognosis discussed with her. The time is 1963, the place is Paris, and one of her daughters is Simone de Beauvoir.

Simone de Beauvoir was a leading French writer, philosopher, and feminist. She wrote The Second Sex, a classic text of feminist literature and several volumes of autobiography. The autobiographical volumes include Memoirs of a Dutiful Daughter, 1958; The Prime of Life, 1960; Force of Circumstance, 1963 and All Said and Done, 1972. De Beauvoir also wrote fiction (perhaps the best known is The Mandarins, published in 1954) philosophy, travel books, and essays, some of them book length, the best known of which is The Second Sex, 1949. A year after her mother's death she wrote $A$ Very Easy Death. ${ }^{1}$ This book is an extremely personal, indeed intimate account of the death of a woman by her daughter. Madame de Beauvoir was abruptly plunged into a cascade of illness, debility, and finally death and we accompany all parties through the frustrations, false hopes, turmoil, and duplicity of her last weeks. At its heart, the book is about a mother and daughter. But it is also a reflection on suffering, family, faith, and mortality. The insights it gives us as health professionals are fascinating-here we have one of the great minds of 20th Century Europe struggling through, and recording with aching honesty, the terminal phase of her own mother's life. This paper reflects on the book, but also on medical practice and the changes brought to that practice by the modern palliative care movement.

The book is a narrative and can be read as such. Through that narrative, however, lie several universal themes. They include:

1. The role of doctors.

2. Information giving and "betrayal".

3. The role of time and change.

4. The vigil.

5. Love of life and grief do not respect age.

6. The power of ritual.

\section{THE DOCTORS}

The depictions of doctors in this book are a study in contrasts. When Mme de Beauvoir collapses at home, a doctor in the same set of apartments assists. Her local doctor takes great umbrage that he was not personally called and refuses to see her. A neighbour is appalled: "After the shock and after her night in the hospital, your mother needed comforting by her usual doctor. He wouldn't listen to a word of it" (De Beauvoir, ${ }^{1}$ p 12).

Various hospital doctors are involved with her care and two are described well-Drs $\mathrm{P}$ and $\mathrm{N}$. Their styles and capacity for communication are very different. When she develops an acute bowel obstruction, $\operatorname{Dr} \mathrm{N}$, who is described as a resuscitation expert, is summoned. When Simone arrives she finds her sister in tears:

"But what's the good of tormenting her, if she is dying? Let her die in peace" ${ }^{\prime \prime}$, said Poupette, in tears...

Dr $\mathrm{N}$ passed by me; I stopped him. White coat, white cap: a young man with an unresponsive face. "Why this tube? Why torture Maman, since there is no hope?" He gave me a withering look. "I am doing what has to be done". He opened the door. After a moment a nurse told me to come in... "Would you like me to have left that in her stomach?" said $\mathrm{N}$ aggressively, showing me the jar full of a yellowish substance. I did not reply. In the corridor he said "At dawn she scarcely had four hours left. I have brought 
her back to life." I did not venture to ask him "For what?" (De Beauvoir, 'pp 27-8)

Later she describes him as "smart, athletic, energetic, infatuated with technique... he had resuscitated Maman with great zeal; but for him she was the subject of an interesting experiment and not a person. He frightened us" (De Beauvoir, ${ }^{1}$ p 52). The doing what had to done was coupled with a mechanical, tactless, and detached manner. Late in the illness Simone records:

When she opened her eyes during the day they had an unseeing, glassy look and I thought, "This time it is the end." She went to sleep again. I asked N, "Is this the end?"

"Oh, no!" he said in a half-pitying, half triumphant tone, "she has been revived too well for that!" (De Beauvoir," p 76)

And again later she narrates:

I spent that night beside her. She was as much afraid of the nightmares as she was of pain. When $\operatorname{Dr} \mathrm{N}$ came she begged, "Let them inject me as often as necessary"...

"Ha, ha, you are going to become a real drug-addict!" said $\mathrm{N}$ in a bantering tone. "I can supply you with morphia at very interesting rates." His expression hardened and he said coldly in my direction, "There are two points upon which a self-respecting doctor does not compromise-drugs and abortion" (De Beauvoir,' $\mathrm{p}$ 79).

It is tempting to view Dr $\mathrm{N}$ as a caricature but de Beauvoir does not write in that fashion and otherwise appears to be recording extremely faithfully.

In contrast, Dr P is altogether warmer. Simone states : "I liked Dr P. He did not assume consequential airs; he talked to Maman as though she were a human being and he answered my questions willingly." ${ }^{1}$ When asked, he promised the sisters that their mother would not suffer. Later, after a very poor day of pain they confront him again:

He came and we seized upon him. "You promised she wouldn't suffer." "She will not suffer". He pointed out that if they had wanted to prolong her life at any cost and give her an extra week of martyrdom, another operation would have been necessary, together with transfusions, and resuscitating injections... But this abstention was not enough for us. We asked P, "Will morphia stop the great pains?" "She will be given the doses that are called for." He had spoken firmly and he gave us confidence. We grew calmer (De Beauvoir, 1 p 82).

"We grew calmer" —-would that this were the epitaph of all our careers!

Communication is a crucial part of medical practice. Currently, communication forms part of undergraduate curricula in many countries. One hopes that modern health professionals respond more sensitively to patients and relatives than was the experience of de Beauvoir. Nevertheless, poor, abrupt, and inadequate communication remains an issue. As Lesley Fallowfield, a leading expert in psycho-oncology, states: "many doctors invest considerable energy cultivating a posture of cool detachment on the grounds that it represents the more professional type of response expected of doctors. Unfortunately patients and relatives can view this detached attitude as evasive, cold, and unsympathetic, occurring at just the time that they are in much need of empathy and support." ${ }^{2}$

The other issue pertinent to modern practice is pain and its management. Mme De Beauvoir pleads with the doctor: "Let me be injected as often as necessary". This entreaty may indeed be a template of the modern approach to analgesia: that pain relief is best provided by regular analgesia with additional (or "breakthrough") doses when required. In the narrative, the issue of analgesia was further complicated by the fear of addiction. Fear of opioid use continues into the modern era and remains one of the many barriers to adequate analgesia. Concern about opioid addiction, tolerance, and dependence plus unrealistic expectations about precipitating adverse side effects all recur in modern surveys of the attitudes of doctors and nurses to opioids. ${ }^{34} \dagger$

Although certainly not universal, opiophobia is coupled with opioignorance, with survey respondents repeatedly acknowledging that they have received insufficient training in or exposure to pain management. ${ }^{5}$

\section{INFORMATION GIVING AND "BETRAYAL"}

Throughout the book, Simone is troubled, and often grievously so, by a sense of betrayal of her mother. Firstly, by allowing the operation to occur, and secondly, in being complicit in withholding the diagnosis from her. In the context of the operation, Simone captures perfectly the sense of responsibility relatives feel in these situations, especially when the choices are viewed as extraordinarily bleak:

And that evening too, as I looked at her arm, into which [the intravenous fluid] was flowing a life that was no longer anything but sickness and torment, I asked myself why?

At the nursing home I did not have time to go into it... But when I reached home, all the sadness and horror of these last days dropped upon me with all its weight. And I too had a cancer eating into me-remorse. "Don't let them operate on her." And I had not prevented anything. Often, hearing of sick people undergoing a long martyrdom, I had felt indignant at the apathy of their relatives. "For my part, I should kill him." At the first trial I had given in: beaten by the ethics of society, I had abjured my own. "No," Sartre said to me. "You were beaten by technique: and that was fatal." Indeed it was. One is caught up in the wheels and dragged along, powerless in the face of specialists' diagnoses, their forecasts, their decisions. The patient becomes their property: get him away from them if you can! There were only two things to choose between on that Wednesday-operating or euthanasia. Maman, vigorously resuscitated, and having a strong heart, would have stood out against intestinal stoppage for a long while and she would have lived through hell, for the doctors would have refused euthanasia...A race had begun between death and torture. I asked myself how one manages to go on living when someone you love has called out to you "Have pity on me" in vain (De Beauvoir," pp 56-8).

Neither the diagnosis nor the prognosis is ever discussed with Mme de Beauvoir. It is a duplicity that is initiated by the doctors but thereafter everyone is complicit. For Simone it constitutes a betrayal. After the operation they ask the

†For a comprehensive list of the reasons why physicians underprescribe analgesics see A M Martino. ${ }^{4}$ 
surgeon: "But what shall we say to Maman when the disease starts again, in another place?" "Don't worry about that. We shall find something to say. We always do. And the patient always believes it" (De Beauvoir, ${ }^{1}$ p 45). Even when her mother asks the question: "Do you think I shall come through?" Simone scolds her (De Beauvoir, ${ }^{1}$ p 65) and immediately regrets it:

My unfair harshness wrung my heart. At the time the truth was crushing her and when she needed to escape from it by talking, we were condemning her to silence; we forced her to say nothing about her anxieties and to suppress her doubts: as it had so often happened in her life, she felt both guilty and misunderstood. But we had no choice: hope was her most urgent need (De Beauvoir, ${ }^{1}$ p 66).

Even though Simone never betrayed this conspiracy of silence she railed against it and clearly saw what openness could bring and what silence could lead to:

...all this odious deception! Maman thought that we were with her, next to her; but we were already placing ourselves on the far side of her history. An evil all-knowing spirit, I could see behind the scenes, while she was struggling, far, far away, in human loneliness. Her desperate eagerness to get well, her patience, her courage-it was all deceived. She would not be paid for any of her sufferings at all...Despairingly, I suffered a transgression that was mine without my being responsible for it and one that I could never expiate (De Beauvoir, p 58).

This silence is maintained and preserved to such an extent that in the very hour of their mother's death, Simone's sister is compelled to respond to an explicit entreaty by her mother:

\footnotetext{
...she murmured in a rather thick voice, "We must... keep...back...desh."

"We must keep back the desk ?"

"No," said Maman. "Death." Stressing the word death very strongly. She added, "I don't want to die".

"But you are better now!" [said Poupette] (De Beauvoir," p 88).
}

Professional and public attitudes to non-disclosure of diagnosis and collusion between relatives and health professionals have, in many countries, changed significantly since the events narrated in this book. There is clear evidence that most North American and European patients wish to be informed about a diagnosis of cancer, ${ }^{6-8}$ and health professionals have changed their practice to reflect these expectations. There is also, however, significant evidence from other cultures that suggests that non-disclosure and collusion with families are common practice. Some cultures perceive the disclosure as a harmful act, violating the principle of nonmaleficence. ${ }^{90}$ Brurea et al surveyed palliative care specialists in French speaking Europe, South America (Argentina and Brazil) and Canada. All the clinicians said they would personally like to be told the truth about their own terminal illness. Whereas 93\% of Canadians physicians thought the majority of their patients would wish to know, only $26 \%$ of European and $18 \%$ of South American clinicians thought so. ${ }^{11}$ Many Chinese families object to telling the patient a "bad" diagnosis or prognosis and doctors in mainland China often inform the family members instead of the patient. ${ }^{12}{ }^{13}$

\section{PALLIATIVE CARE}

A further dilemma reflected upon in the book is the stark choice de Beauvoir sees confronting her mother, between "operating or euthanasia" and then, postoperatively, "between death and torture". In retrospect, a third alternative was palliative care. The events of the narrative preceded the modern palliative care movement. Indeed, it was precisely clinical situations such as this narrative reveals, and the recognition of the inadequacy of symptom control and end of life care that motivated the pioneers of that movement. That movement's founding and primary aim is to care for all people with life threatening illnesses and their families. The most recent definition of palliative care by the World Health Organization includes the objective of "early identification and impeccable assessment and treatment of pain and other problems, physical, psychosocial and spiritual". Palliative care, as practised today would have been perfect for the situation described: better symptom control, anticipation of worsening symptoms, attention to the psychosocial and spiritual needs of the patient, and assisting the relatives in the vigil leading to the patient's death. Indeed, this book would provide a useful teaching exercise in palliative care education. Among many questions that the narrative raises, one that could be posed to students would be: how would a modern palliative care service deal with the challenges faced by the patient and her family?

\section{TIME AND CHANGE}

Mme de Beauvoir had an unhappy childhood. She brought at least some of that unhappiness into her role as a mother. Simone describes her mother as difficult, possessive, and overbearing. "Her love for us was deep as well as exclusive, and the pain it caused us as we submitted to it was a reflection of her own conflicts...With regard to us, she often displayed a cruel unkindness that was more thoughtless than sadistic: her desire was not to cause us unhappiness but to prove her own power to herself"' (De Beauvoir, ' p 40). Simone pictures her as an unhappy woman who struggled with both her desires and her daughters:

Thinking against oneself often bears fruit; but with my mother it was another question again - she lived against herself. She had appetites in plenty: she spent all her strength in repressing them and she underwent this denial in anger. In her childhood her body, her heart and her mind had been squeezed into an armour of principles and prohibitions. She had been taught to pull the laces hard and tight herself. A full blooded, spirited woman lived on inside her, but a stranger to herself, deformed and mutilated (De Beauvoir, 'pp 42-3).

However, a strange thing happens. As Simone visits her mother she notices changes in her mother, changes in herself, and finally an outpouring of love and grief that is both powerful and unexpected. For the first period of her illness, Mme de Beauvoir remains difficult and emotionally demanding, but then, vulnerable and recovering, glimpses of another self emerge:

What touched our hearts that day was the way she noticed the slightest agreeable sensation: it was as though, at the age of seventy eight, she were waking afresh to the miracle of living. While the nurse was settling her pillows the metal of a tube touched her thigh-"It's cool! How pleasant!" She breathed in the smell of eau de Cologne and talcum powder- "How good it smells"... She asked us to raise the curtain that was covering the window and 
she looked at the golden leaves of the trees. "How lovely. I shouldn't see that from my flat!" She smiled. And both of us, my sister and I, had the same thought: it was that same smile that had dazzled us when we were little children, the radiant smile of a young woman. Where had it been between then and now? (De Beauvoir, 1 p 50)

The softening continues.

Her illness had quite broken the shell of her prejudices and her pretensions: perhaps because she no longer needed these defences. No question of renunciation or sacrifice any more: her first duty was to get better and so to look after herself; giving herself up to her own wishes and her own pleasures with no holding back, she was at last freed from resentment. Her restored beauty and her recovered smile expressed her inner harmony and, on this deathbed, a kind of happiness (De Beauvoir, ${ }^{1}$ p 60).

Finally, after days of sitting with her mother Simone reflects:

I had grown very fond of this dying woman. As we talked in the half darkness I assuaged an old unhappiness; I was renewing the dialogue that had been broken off during my adolescence and that our differences and our likenesses had never allowed us to take up again. And the early tenderness that I thought dead for ever came to life again, since it had become possible for it to slip into simple words and actions (De Beauvoir,' p 76).

\section{GRIEF AND LOVE OF LIFE DO NOT NECESSARILY RESPECT AGE}

Mme de Beauvoir is 78 years old. Her daughter is content, almost as a reflex, to initially consider this is "of an age to

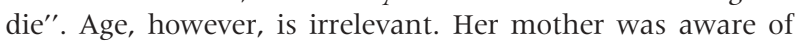
this much earlier than her daughter. Simone writes of her mother: "She believed in heaven, but in spite of her age, her feebleness, and her poor health, she clung ferociously to this world, and she had an animal dread of death" (De Beauvoir, p 14).

It was that ferocity that her daughter came to understand. Her mother's loss she came to see as a form of defeat where time and age were irrelevant. After the funeral she reflects on how empty is the sentiment "they are of an age to die":

The sadness of the old; their banishment: most of them do not think that this age has yet come for them. I too made use of this cliché, and that when I was referring to my mother. I did not understand that one might sincerely weep for a relative, a grandfather aged seventy or more. If I met a woman of fifty overcome with sadness because she had just lost her mother, I thought her neurotic: we are all mortal; at eighty you are quite old enough to be one of the dead...

But it is not true. You do not die from being born, nor from having lived, nor from old age. You die from something. The knowledge that because of her age my mother's life must soon come to an end did not lessen the horrible surprise: she had sarcoma. Cancer, thrombosis, pneumonia: it is as violent and unforeseen as an engine stopping in the middle of the sky... There is no such thing as a natural death: nothing that happens to a man is ever natural, since his presence calls the world into question. All men must die: but for every man his death is an accident and, even if he knows it and consents to it, an unjustifiable violation (De Beauvoir, 1 pp 105-6).

\section{THE VIGIL}

In one sense, the book is a daily description of a vigil-a 6 weeks long wait by their mother's bedside. For both Simone and her sister the vigil becomes their reality. As doctors we have all witnessed this aspect of the dying process - the daily visits by relatives and friends, the harried looks as they search for any changes, however small or transient in their loved one, the sleepless nights either at home or next to the patient in the hospital or hospice, the whispered family discussions, the long periods of inactivity, the shared silence. De Beauvoir captures well the heightened sense of reality that comes with the intensity of the wait and also the sense that, throughout this long period, nothing else matters:

The world has shrunk to the size of her room: when I crossed Paris in a taxi I saw nothing more than a stage with extras walking on it. My real life took place at her side, and it had only one aim-protecting her. In the night the slightest sound seemed huge to me-the rustling of Mademoiselle Cournot's paper, the purring of the electric motor. I walked in stockinged feet in the daytime. The coming and going on the staircase, and overhead, shattered my ears. The din of the wheeled tables that went by on the landing...loaded with clattering metal trays, cans and bowls, seemed to me scandalous" (De Beauvoir, 1 p 76).

Equally, de Beauvoir depicts how her view of her world, even outside the confines of the hospital, has changed irrevocably:

I had the feeling of play acting wherever I went. When I spoke to an old friend ...the liveliness of my voice seemed to me phoney: when with perfect truth I observed "That was very good" to the manager of a restaurant, I had the impression of telling a white lie. At other times it was the outside world that seemed to be acting a part. I saw a hotel as a nursing-home; I took the chambermaids for nurses; and the restaurant waitresses too-they were making me follow a course of treatment that consisted of eating. I looked at people with a fresh eye, obsessed by the complicated system of tubes that was concealed under their clothing. Sometimes I myself turned into a lift-andforce pump or into a sequence of pockets and guts (De Beauvoir, 'pp 74-5).

\section{THE RITUAL OF DEATH}

Once their mother had died the shock came in waves, and often unexpectedly, for both of her daughters. Returning to the hospital on the morning after her death they face an empty room. Their world for the past weeks was literally bare:

Once again we climbed the stairs, opened the two doors: the bed was empty...on the whiteness of the sheet there was nothing. Foreseeing is not knowing: the shock was as violent as though we had not expected it at all (De Beauvoir, 1 p 96).

Throughout the book de Beauvoir honestly concedes that a purely material or rationalist approach to the dying and death 
of her mother neither does nor should apply. Even with the immediate aftermath of her mother's death, Simone finds regret:

But I did reproach myself for having abandoned her body too soon. She, and my sister too, said "A corpse no longer means anything". Yet it was her flesh, her bones, and for some time still her face. With my father I had stayed by him until the time he became a mere thing for me: I tamed the transition between presence and the void. With Maman I went away almost immediately after having kissed her, and that was why it seemed to me that it was still her that was lying, all alone, in the cold of the mortuary (De Beauvoir, 1 p 97).

This sense of the unique, the individual, even the sacred extends beyond their mother's body to simple, even prosaic objects:

As we looked at her straw bag, filled with balls of wool and an unfinished piece of knitting...her scissors, her thimble, emotion rose up and drowned us. Everyone knows the power of things: life solidified in them, more immediately present than in any one of its instants. They lay there on my table, orphaned, useless, waiting to turn into rubbish or to find another identity... (De Beauvoir, p 98).

De Beauvoir concludes that what they face is not rational:

It is useless to try to integrate life and death and to behave rationally in the presence of something that is not rational: each must manage as well as he can in the tumult of his feelings. I can understand all last wishes and the total absence of them: the hugging of the bones or the abandonment of the body of the one you love to the common grave (De Beauvoir,' p 98).

\section{CONCLUSION}

Inevitably, de Beauvoir reflects at the end of the book on the events of the prior months. Equally such reflection centres on the rapidity of the disease and her role as her mother's daughter. There are layers of self reproach and balancing out "respite" and "remorse":

And is one to be sorry that the doctors brought her back to life and operated, or not? She, who did not want to lose a single day, "won" thirty: they brought her joys; but they also brought her anxiety and suffering. Since she did escape from the martyrdom that I sometimes thought was hanging over her, I cannot decide for her. For my sister, losing Maman the very day she saw her again would have been a shock from which she would scarcely have recovered. And as for me? Those four weeks have left me pictures, nightmares, sadnesses that I should never have known if Maman had died that Wednesday morning. But I cannot measure the disturbance that I should have felt since my sorrow broke out in a way that I had not foreseen (De Beauvoir,' pp 93-4).

Illness and death brought to an aching, almost exquisite, focus the importance and the place of her mother. In describing this she eloquently stated the complexity of all close relationships-the uniqueness, the joys, and the regrets:
We did derive an undoubted good from this respite [after the operation]; it saved us, or almost saved us, from remorse. When someone you love dies you pay for the sin of outliving her with a thousand piercing regrets. Her death brings to light her unique quality; she grows as vast as the world that her absence annihilates for her and whose whole existence was caused by her being there; you feel that she should have had more room in your lifeall the room, if need be. You snatch yourself away from this wildness: she was only one among many (De Beauvoir, 'p 94).

The regrets are finally balanced against the closeness, intimacy, and solicitude of the final weeks:

But since you never do all you might for anyone-not even within the arguable limits that you have set yourself-you have plenty of room left for self reproach. With regard to Maman we were all guilty, these last years, of carelessness, omission, and abstention. We felt that we atoned for this by the days that we gave up to her, by the peace that our being there gave her, and by the victories gained over fear and pain. Without our obstinate watchfulness she would have suffered far more (De Beauvoir, ${ }^{1} \mathrm{p}$ 94).

The book raises many points for reflection. In terms of clinical practice, the themes of adequacy of symptom control, opiophobia, sensitivity and clarity in communication and disclosure versus collusion, remain as relevant today as they did then. Certainly our capacity to meet those challenges has developed significantly. As a piece of literature this book is beautifully written. As an account of one individual's terminal illness it superbly captures the rhythms of the progression of a disease. As a reflection by a daughter on her mother it is strikingly honest and raw. The illness and death of Mme de Beauvoir brought an extraordinary array of emotions to the surface, for many of which Simone was unprepared. In confronting those, de Beauvoir gives the reader, medical or otherwise, an insight into the universal currents that flow through all our lives both personally and professionally-the sadness of loss, the ambivalence and complexity of children's relations with their parents, the solace that comes with time and reflection, the uniqueness of all lives, and the sense of violation when that life has ceased. It is that testimony and those insights that make this a document of great richness.

\section{REFERENCES}

1 De Beauvoir S. A very easy death. New York: Pantheon Books, 1985.

2 Fallowfield L. Communication and palliative medicine. In: Doyle D, Hanks G, Cherny NI, et al. Oxford textbook of palliative medicine [3rd ed]. Oxford University Press, 2003:103.

3 Pargeon KL, Hailey BJ. Barriers to effective cancer pain management: a review of the literature. J Pain Symptom Manage 1999; 18:358-68.

4 Martino AM. In search of a new ethic for treating patients with chronic pain: what can medical boards do? J Law Med Ethics 1998;26:332-49.

5 Elliott TE, Elliott BA. Physicians' attitudes and beliefs about use of morphine for cancer pain. J Pain Symptom Manage 1992;7:141-8.

6 Blanchard C, Labreque M, Ruckdeschel J, et al. Information and decision making preferences of hospitalised adult cancer patients. Soc Sci Med 1988:27:1139-45.

7 Cassileth B, Zupkis R, Sutton-Smith K, et al. Information and participation preferences among cancer patients. Ann Intern Med 1980;92:832-6.

8 Meredith C, Symonds P, Webster L, et al. Information needs of cancer patients in west Scotland: cross sectional survey of patients' views. BMJ 1996;313:724-6.

9 Blackhall L, Murphy S, Frank G, et al. Ethnicity and attitudes toward patient autonomy. JAMA 1995;274:820-5. 
10 Mitchell JL. Crosscultural issues in the disclosure of cancer. Cancer Pract 1998;6: 152-60.

11 Brurea E, Neumann CM, Mazzocato C, et al. Attitudes and beliefs of palliative care physicians regarding communication with terminally ill patients. J Palliat Med 2000;14:287-98.
12 Pang SMC. Protective truthfulness: the Chinese way of safeguarding patients in informed treatment decision. J Med Ethics 1999;25:247-53

13 Li S, Chou JL. Communication with the cancer patient in China. Ann N Y Acad Sci 1997;809:243-8

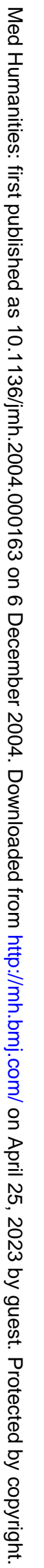

